\title{
Characterisation of Thomas in the Fourth Gospel
}

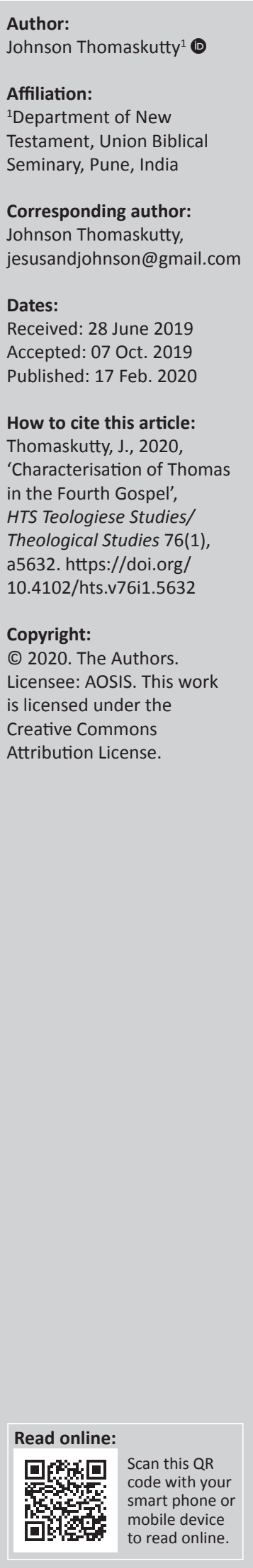

Thomas appears four times within the narrative framework of the Fourth Gospel (Jn 11:16; $14: 5 ; 20: 24-28 ; 21: 2)$. His presence in the Gospel introduces some of the strategic transitions within the macro-narrative structure. The following are some of the crucial moments that are introduced through the entry of Thomas: firstly, Thomas' character is brought to the foreground towards the end of Jesus' public ministry, where a transition is underway through Lazarus' death and raising to Jesus' death and resurrection (11:16); secondly, he appears as a significant interlocutor engaged in dialogue so that Jesus' identity as 'the way, the truth, and the life' may be revealed to the disciples during his private ministry (Jn 14:5-6); thirdly, Thomas' character appears towards the climax of the Book of Glory as he is instrumental in revealing the identity of Jesus as 'Lord' and 'God' (Jn 20:24-29); and fourthly, he appears as one of the seven disciples during the post-resurrection context in Galilee (Jn 21:2). The unique placement of Thomas communicates something significant about the character and his development within the narrative.

Keywords: characterisation; John's Gospel; Thomas the Apostle.

\section{Introduction}

Thomas appears four times within the narrative framework of the Fourth Gospel (see Jn 11:16; $14: 5 ; 20: 24-28 ; 21: 2)$. His presence in the Gospel introduces some of the strategic transitions to the macro-narrative structure (see Skinner 2009:43). The following discussions are some of the crucial moments introduced through the entry of Thomas: firstly, Thomas' character is brought to the foreground towards the close of Jesus' public ministry, where a transition is in view from Lazarus' death and raising to Jesus' death and resurrection (Jn 11:16) ${ }^{1}$; secondly, he appears as a significant interlocutor engaged in a dialogue so that Jesus' identity as 'the way, the truth, and the life' may be revealed to the disciples during his private ministry (Jn 14:5-6); thirdly, Thomas' character appears towards the climax of the Book of Glory (Jn 13:1-20:31) as he is instrumental in revealing the identity of Jesus as 'Lord' and 'God' (Jn 20:24-29); and fourthly, he appears as one of the seven disciples during the post-resurrection context in Galilee (Jn 21:2). Although Thomas' character is absent at the beginning of the Gospel, his presence is significantly noticeable in the above-stated transitions. The narrator orchestrates the extended story of the Gospel with a view of Thomas at the transitions.

The unique placement of Thomas communicates something significant about the character and his development within the narrative. A careful analysis of the four appearances of Thomas, that is, within the episodes they appear and within the extended narrative framework of John, calls the attention of the reader towards some of the vital areas in the story. In the following sections, we look into those aspects through an exegetical analysis.

\section{From Lazarus' death to Jesus' death (Jn 11:1-12:11)}

The narrator introduces Thomas in Chapter 11 and the reader gets an impression that he was there with Jesus right from the beginning of his public ministry. That further means that he was following Jesus passively until now as an implicit and backgrounded character (see Skinner 2009:43). In John 11:16, the passive, implicit and backgrounded Thomas comes out as an active, explicit and foregrounded character. The narrator of the story uses Thomas' question in verse 16 as a significant statement to tell the story of Jesus dynamically. ${ }^{2}$ Thomas' saying about going and

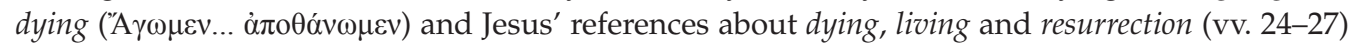
are integrally connected (cf. Collins 1990:84-85). Why is Thomas introduced at the high point of the public ministry of Jesus? Sylva (2013) states that: 1.Skinner (2009:55) states further: "Here, Thomas serves as a foil, being used by the narrator to create a situation where narrative
tension, irony, and misunderstanding point forward to the illumination given by the "light of the world"'.

2.Byrne (1991:67-68) considered John 12:1-11 as a well-connected pericope to the story of Lazarus in John 11:1-57. 
Thomas appears first at the turning point of the narrative, at the point where John is making clear that the significance of Jesus' signs is that they show that he is the one who gives eternal life. (p. 11)

Thomas appears here as a foil character to bring to the fore the aspects of the 'death' of Jesus without shifting the attention of the reader away from the protagonist (see Popp 2013:50; Thompson 2015:242).

The narrator attempts to reveal a truth through constellations of words and expressions within the narrative framework. The network of expressions such as going, dying, faith, glory, love and others is significant to note within the narrative master plan (see Duke 1985:59-61; Köstenberger 2004:331-332). According to Popp (2013:504), 'the Thomas texts are not conclusive but are, rather, through their polyvalence, open to diverse interpretive possibilities' (see Collins 1990:84-85). Although Martha comes as the key character and confessor of Jesus in the following sections (Jn 11:17-44), her role as a whole is restricted within the present episode. But Thomas advances from here until the end of the extended Johannine story (see Byrne 1991:46-47). Thomas is said to have prepared the rest of the disciples for Jesus' forthcoming death (see Bowman 1975:246; Hendriksen 1954:144-145). In the following sections we observe how a network of expressions helps us to understand the very essence of Thomas' statement in John 11:16.

\section{'Let us also go ...'}

The theme of going appears continuously within this narrative framework. It begins with the utterance of Jesus in John 11:7: 'Let us go to Judea again'. ${ }^{3}$ Jesus' statement here is filled with missional implications as he is stepping forward for accomplishing a task. Jesus' very movement was at stake as the disciples pose a question in verse 8: 'Rabbi, the Jews were just now trying to stone you, and are you going there again?'4 Going ahead, irrespective of growing oppositions or threat to death, is part and parcel of Jesus' mission initiatives (see Howard-Brook 1997:77). After these preliminary remarks based on the going language, the narrator introduces Thomas to the foreground with his significant utterance.

The utterance of Thomas in verse 16, 'Let us also go ['A $\gamma \omega \mu \varepsilon v]$ ', introduces a radical step at this critical juncture (see Bultmann 1971:400; Carter 2006:75). On the one hand, he takes a challenge to go against the majority view, and on the other hand, he decides to align himself to the view of Jesus that was not pleasant to the rest of his companions (v. 16). Popp (2013) argues that:

His [Thomas'] entrance is unmediated and abrupt. He is suddenly present as an acting character and addresses his 'fellow disciples'

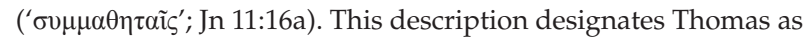
a member of the group of disciples, thus also implying his obligation to follow Jesus. (p. 507)

3.The subjunctive plural verb is a derivation of ' $\alpha p \omega$ ', which means 'to lead'. See Newman and Nida (1980:358).

4. Indicative present active singular verb means 'to depart'.
In that sense, Thomas' statement takes the spirit of Jesus' missional concerns at its highest esteem (cf. Sylva 2013:11). His utterance is in the sense that as Jesus goes, let us also go with him.

While Martha and Mary went to meet Jesus to convey their grievances concerning their brother's death (vv. 20, 29), Thomas shows a superior missional model as he encourages his colleagues to go with Jesus even if there is danger ahead (Haenchen 1984:2:60; Von Wahlde 2010:2:484-502). He stands apart and understands the real meaning of Jesus' going. He was able to perceive Jesus' going synonymous to his death. As Bonney (2002:138) states: 'The journey will lead to the crucifixion of Jesus (cf. Jn 11:45-53)'. Thomas acts here as the spokesman for the 12. He shows willingness to go with Jesus, who was leading them to death, and to share the danger ahead.

\section{'... That we may die with him'}

As we have seen, the linguistic phenomena help us to understand the characterisation. The speech and behaviour of Thomas are important narrative clues to perceive his personality (see Petersen 1993). Thomas' utterance, 'that we may die with him [Jesus]', works in a dynamic rhythm with other narrative and utterance units (cf. Byrne 1991:47). Charlesworth (1995:238) states that:

He [Thomas] exhorts his fellow disciples to follow Jesus back into Judea, even if it means martyrdom: 'Thomas, called the Twin, said to his co-disciples, Let us also go, that we may die with him (Jn 11:16)'. (p. 238)

Thomas' utterance is a narrative clue that reminds the reader that the death of Lazarus is told as a 'minor story' to present the 'major story' of Jesus with symbolical effect (see Bonney 2002:137-138).

The resolution of John's story takes shape in the current episode as it merges Lazarus' death and resurrection symbolically with the death and resurrection of Jesus (see Stibbe 1994:24-25). The analeptic statement in verse 2 (as a reference to Jn 12:7) attunes the reader's attention towards the death and burial of Jesus. In Jesus' statement in verse 4 it is made clear that Lazarus' death and resurrection are for God's glory, so also for the glory of the Son of Man. Here, the death and glorification of the Son of Man are in view. Thomas' utterance in John 11:16 is a great pointer towards that extended story of the Gospel (see Bonney 2002:138; Stibbe 1993:125). Jesus' determination to go to his own death and his glorification is strongly supported by the remarkable voice of Thomas (see Moloney 1996:159). Lincoln (2005) says:

Thomas' comment is truer than he suspects. In the case of Jesus what he does not yet know but what the narrator will recount is that it is precisely Jesus' act of raising Lazarus that will trigger off the events that finally lead to his death. (p. 322)

The revelatory utterance of Jesus, 'I am the resurrection and the life' (v. 25), has to be interpreted also as a reaction to the 5.Although Mary's exemplary activity is narrated in John $11: 2$ and $12: 1-8$, her role, as in the case of Martha, is restricted within this episode. 
utterance of Thomas in John 11:16 (see Rensberger 1988:120; Waetjen 2005:275). The narrator uses Martha and Mary Magdalene as key figures in developing the story of Lazarus. On the contrary, he uses Thomas as the key figure to attune the story to the extended level (see Story 1997:243).

Within the extended framework of John's story, the utterance of Thomas creates a prolepsis with the passion and death of Jesus. Thomas' entry from the background to the foreground spearheads one of the dramatic initiatives of the narrator to develop the story with suspense and surprise. The narrative setting provides special punch for the involvement of Jesus as the life-giving saviour in the family of Lazarus. But Thomas shifts the attention of the reader away from Lazarus and his death and resurrection to the upcoming event of Jesus' death. The willingness of Thomas to go with Jesus irrespective of the risk of life demonstrates his unique identity as a character. Charlesworth (1995:125) says, "The leadership role of Thomas was made clear in [C]hap. 11, when he exhorted his fellow disciples to follow Jesus even if it meant death (Jn 11:16)'. The death of Jesus and the climax of John's story are prefigured through the utterance of Thomas. Thomas stands against all odds, and confirms his reaction positively to Jesus and his plans. The glorification aspect accelerates towards its climax as Thomas shifts the focus from Lazarus to Jesus.

Although Thomas does not add any Christological title in his speech, his utterance marks a crucial Christological turn within and beyond the episode.

\section{Knowing the way (Jn 13:1-17:26)}

After introducing Thomas to the reader in John 11:16, the Johannine narrator foregrounds him another time in John 14:5 (see Bruce 1983:298-299). The utterance of Thomas within the Farewell Discourse resonates with other themes, character utterances and narrative comments. While Thomas' first utterance was a significant one towards the end of Jesus' public ministry in the Book of Signs, his second utterance in the private ministry section provides additional punch to the previous utterance (see Sylva 2013:64). In the following sections, we analyse how the utterance of Thomas resonates within the Farewell Discourse of John's Gospel.

\section{'Lord, we do not know where you are going ...'}

The second utterance of Thomas (Jn 14:5) is yet another enigmatic statement that has to be explored alongside several other factors. While Thomas does not use any Christological titles to address Jesus (but only ' $\alpha$ vĩoṽ') in his previous utterance (Jn 11:16), in John 14:5 he uses one of the extensively used titles, 'אúpıos' (cf. Fitzmyer [1981]1991:329). It explicitly states that there is a development from the former appearance and utterance to the latter. The Farewell Discourse uses the title 'кúpros' either as an address of the disciples to Jesus (Jn $13: 6,9,25 ; 14: 5,8,22)$ or as a self-revelatory description by Jesus himself (Jn 13:13, 14, 16; 15:15, 20).
Thomas uses a title that was familiar: firstly, it was used by Jesus as a self-revelatory description, and secondly, it was used by his colleagues to address their master (see Bruner 2012:811-812).

The unknowing nature of Thomas contributes semantic domains within the statement-misunderstanding-clarification narrative framework (see Neyrey 2007:243; cf. Bennema 2009: 164-170). Sylva (2013:80-81) states: 'Thomas' understanding is found deficient because, loyal as he is, he has not come to know the essence of Jesus' being and the Father that this essence reveals' (cf. Schnackenburg 1982:3:64). What Sylva states here is true as Thomas reflects his character in his own idiom. John depicts the aspect of knowing at three levels: firstly, the allknowing nature of Jesus; secondly, the ignorant nature of the world from below; and thirdly, Thomas and his colleagues are progressive as they begin to know.

Thomas' expression we do not know reveals this fact explicitly to the reader (see Popp 2013:512-513). As a person lives in the world from below and understands the mysteries of the things from above, Thomas' character shows dullness and progress at the same time (see Barrett 1962:382; Blomberg 2001:198)

Thomas represents a leading person among the disciples, but at the same time he expresses his views on his own terms (see Brouwer 2000:90; Popp 2013:512). Even after their continuous acquaintance with Jesus, the disciples are unable to understand him (Jn 14:9) and his deeds (Jn 13:7). In that sense, Thomas' perplexities in John 14:5 could be understood in the following ways: firstly, as a human, he was thinking and knowing things from the point of view of this world; secondly, as a follower of Jesus, he is aware of the things from above (because Jesus makes things known to him; Jn 17:26); and thirdly, as a person who has dual identity, he is perplexed (but Jesus will make things known to him, Jn 17:26; cf. Popp 2013:512). These past, present and future aspects reveal some of the significant aspects of the characterisation of Thomas (see Sylva 2013:81). Thomas as a person under training was not able to perceive mysterious things, but Jesus promises that he will make all things known to him later (Jn 17:26; see Popp 2013:512).

The vocabulary of going is another significant aspect in the Farewell Discourse to reckon with. Thomas' statement, 'We do not know where you are going', should be looked at from the constellation of that linguistic phenomenon. In this way, as far as the character analysis is concerned, Jesus and Thomas (explicitly in Jn 14:5 and implicitly in Jn 14:31) are brought into contact with one another (see Blomberg 2001:198). From Thomas' utterance, three things are significant to note: firstly, in John 11:16, Thomas recognises that Jesus' going is for his death; secondly, Thomas is not able to see beyond Jesus' death and perceive the connection between his death and going to the Father; and thirdly, while Thomas recognises that Jesus is going to die in John 11:16, he fails to understand Jesus' death as a marking point for him to go to the Father. 


\section{'How can we know the way?'}

Thomas' utterance in John 14:5 ends with a significant question: 'How can we know the way?' (see Brant 2004:105). Carson (1991) maintains that:

[H] is [Thomas'] question sounds as if he interpreted Jesus' words in the most crassly natural way: he wants an unambiguous destination, for without such a destination how can one meaningfully speak of the route there? (see Carson 1991:490; cf. Bultmann 1971:603-604)

Thomas' identity, which is caught between the world from below and the world from above, makes him ask this question (see Bonney 2002:139). In John, the hour of Jesus is connected to the way to the cross (Jn 13:1; 17:1). At the same time, it marks his departure from this world (Jn 13:1; 16:5). DeConick (2001) states as follows:

The author, by deliberately characterizing Thomas as a fool in this passage, condemns the hero of the Thomasine Christians. Moreover, his articulation of the discourse points to a particular feature of the dispute: the journey or ascent to heaven. John tells us that such ascent is not necessary, that Jesus himself is the only 'way' into heaven. This is stated in contradiction to the Thomasine belief which, from Thomas' answer in 14:5, appears to have encouraged proleptic heavenly ascents. (p. 73)

From Jesus' utterance in John 14:7, 'None comes to the Father except through $\mathrm{me}^{\prime}$, one perceives that Jesus is the way that God opened to the world. Similarly, Jesus is the one who prepares a way backward to the Father. Jesus' mission of preparing a home for the faithful is in the process of its realisation (Jn 14:3; see Barrett 1962:381-382). Peter's question in John 13:36 ('Lord, where are you going?') and Thomas' question in John 14:5 ('How can we know the way?') are to be perceived from this ideological constellation (see Moloney 1998:393). The conversation between Philip and Jesus in John 14:8-14 strengthens this subject matter further. Jesus speaks figuratively in saying that 'In my Father's house there are many dwelling places' (Jn 14:2), 'Where I am, you also may be' (Jn 14:3) and 'You know the way to the place where I am going' (Jn 14:4). The narrator highlights the utterance of Jesus, 'I am the way, the truth, and the life' (Jn 14:6), as the epitome of the extended discourse. The coming of the Holy Spirit (Jn 14:16-17, 26; 15:26-27; 16:7-8, 13-15) further assures that Jesus had opened the way from/to heaven.

John also shows an antagonistic movement against the way: betrayal as the way of Satan (Jn 13:2, 18, 21, 26-30; 17:12), the coming of the ruler of the world (Jn 14:30; 16:11), the hate of the world towards the children of God (Jn 15:18-25; 17:15) and the hour of the enemy (Jn 16:2-4; see Brant 2004:220-224). Jesus as the way to God introduces a new ethical paradigm over against the ways of Satan. Through the mediation of Jesus, the world from above ushers in the world from below. In this context, Thomas' question functions in the following ways: firstly, it helps as a pointer for the reader to understand the sharp contrast between the from-below and from-above ideologies; secondly, it is used as a rhetorical device to draw the attention of the reader towards Jesus, the protagonist, and his revelation as the way, truth and life (see Schnackenburg 1982:64); and thirdly, it helps the reader to identify herself or himself with Thomas to develop from going to die aspect (Jn 11:16) to going to the Father aspect (Jn 14:5; see DeConick 2001:72-73).

The utterance of Thomas in John 14:5 provides further understanding about his person and his ideological framework. The shift of emphasis from the previous utterance (Jn 11:16, 'going to Jerusalem and to death') to the latter (Jn 14:5, 'to the Father') has to be noticed in the process of reading the text. The narrator places the utterances of Thomas in John 14:5 to develop the plot structure with suspense and surprise.

Thomas' question adds rhetorical punch for the Farewell Discourse and it has both analeptic and proleptic functions within the narrative master plan. Thomas' role as a character that represents the rest of the disciples initiates some of the significant revelatory aspects in the Gospel. As we had already noted, the speech unit of Thomas has the following emphases: firstly, the title Lord has a specific emphasis when it is compared with the rest of the usages; secondly, the narrator explores the narratorial technique of knowing-andunknowing contrast in its maximum; thirdly, the aspect of going is introduced with a different emphasis when it is compared with John 11:16; and fourthly, the question 'How can we know the Way?' ushers some of the revelatory and mysterious truths related to the heavenly realities and the existential struggles of the believers.

Thomas is unique in his approach to belief as he is a seeker of truth through evidence, as he believes on the basis of seeing, and as he shows inclination towards an action-oriented and progressive movement. His character shows love and concern towards Jesus and his utterances, exemplifies frankness in speech, willingness to die for Jesus and to represent his colleagues in crucial junctures, and requires time to accept the truth of Jesus. Thomas stands tall as a character who takes the initiative to communicate the glorification aspect convincingly to the rest of the disciples or readers. Thus, Thomas emerges as a stable character and one who adds rhetorical force to the plot-structure of the story.

\section{Recognising Jesus as 'Lord' and 'God' (Jn 20:1-31)}

John 20:1-31 is the last episode of the Book of Glory in which Thomas appears for the third time (see more details in Thompson 2015:423; cf. Bonney 2002:145-167). In the episode, the character of Thomas can be fully understood only in comparison to the rest of the characters and their utterances. The utterances of Mary Magdalene and the other disciples are to be compared with that of Thomas to understand the unique presence of Thomas. The extreme statements of Thomas, one to the rest of the disciples (v. 25b) and one to Jesus (v. 28), make his appearance convincing within the episode. While on the one hand, he says to the disciples that 
'unless I see ... put my finger ... I will not believe', and on the other, he utters to Jesus 'My Lord and my God!' (see Thomaskutty 2018:54-74).

\section{'Seeing and putting finger in the mark of the nails'}

The vocabulary of seeing is rich in John 20 and that has to be analysed seriously to understand the utterances of Thomas in verses 24-29. Thomas' determination to see tangible evidence is made clear through his conditional statement in verse 25b (see Bruce 1983:393; cf. Sylva 2013:84-87). His conviction about his faith in Jesus compels the reader to evaluate him in relation to the rest of the characters. While the leading characters of John 20, Mary Magdalene and the disciples (including Peter and the other disciple), declare in both individual and corporate life that they have seen the Lord, Thomas stands out at a different level (see Sylva 2013:82-83; see Haenchen 1984:2:211). Thomas did not see Jesus as in the case of Mary Magdalene and the other disciples. He declares that unless he sees and touches tangible evidence that Jesus is alive he will not believe (v. 25). ${ }^{6}$ Jesus takes the challenge, comes to him in the presence of others and says to him: 'Put your finger here and see my hands' (v. 27). Jesus' question in verse 29a ('Have you believed

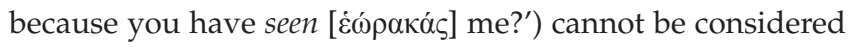
as an exclusive response to Thomas, but has to be looked at as one to Thomas, Mary Magdalene, Peter, the other disciple and the rest of the disciples. ${ }^{7}$

Similarly, his macarism in verse $29 \mathrm{~b}$ cannot be reckoned as an exclusive criticism to Thomas, but has to be understood as one to the disciples and Mary Magdalene (see Bennema 2009:167). Thomas comes out here as a figure who can better conclude the story of Jesus in the Gospel. By placing Thomas, one of the leading figures of early Christianity, at centre stage, the narrator deciphers the early Christian trend of seeing and believing (see Thompson 2015:243-244).

Thomas' demand for touching the mark of the nails in Jesus' hands requires special attention (cf. Schnackenburg 1984:318). Although Thomas demands to touch the body of Jesus, there is no mention that he literally touched the body (see Barrett 1962:476). But a reader can infer that Jesus' command to put his [Thomas'] finger in his hands would have been wholeheartedly accepted by Thomas (v. 27; cf. v. 25b). Mopsuestia (2010:166) comments: 'And when [Thomas] ever so carefully touched him and accurately ascertained the truth, he confessed his fault saying, My Lord and My God!' Thomas' statement makes it clear that Jesus' hands were nailed and he himself was a witness of the incident. Both the Synoptic Gospels and John do not give details concerning nailing the hands (and also legs) of Jesus. Thomas is the first and the only person who talks about the mark of the nails

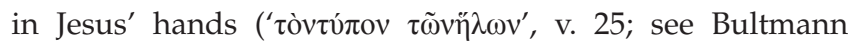
1971:694). In his response to Thomas, Jesus also makes

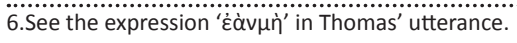

7.To foreground the aspect of seeing, the narrator uses a wide variety of vocabularies. a mention: 'Put your finger here and see my hands' (v. 27a; cf. Brant 2004:88).

Thomas' utterance concerning seeing and putting his finger on the mark of the nails is the only explicit reference about marks in the hands of Jesus. ${ }^{8}$ His statement leads us to the following observations: firstly, there is every possibility that Thomas was an eyewitness of the crucifixion and that he saw Jesus' hands were literally nailed by the soldiers; secondly, while the other disciples took the matter of Jesus' crucifixion in a regular sense, Thomas took that in a more serious sense; thirdly, the wounded psyche of Thomas led him to keep himself away from the other disciples and to take an altogether different stand in his faith and discipleship; fourthly, as one who was willing to go and die with Jesus and who wanted to know the 'way', he was perplexed in his faith-journey to have tangible evidences; fifthly, the narrator presents Thomas on par with Mary Magdalene as both of them saw, touched and declared their faith-reactions, while others could only see and declare in unison; sixthly, he represents all those who are determined for a good reason to believe and proves himself and his faith through seeing, touching and proclaiming; and finally, the narrator wanted to present him even above Mary Magdalene as Thomas' character was brought remarkably at the climax of the story. These factors prove the fact that Thomas was placed above all (even above Peter, the Beloved Disciple and Mary Magdalene) and brings a convincing climax to the story of Jesus in John. ${ }^{9}$

\section{... And putting hands in the side, I will not believe'}

As a matter of belief, Thomas also wanted to put his hands on the side of Jesus (see Mopsuestia 2010:165-166). In that sense, Thomas' utterance in John 20:25 forms an analepsis with the text in John 19:31-37. The narrator describes the events of the passion in an ironical fashion: firstly, the Jews got permission from Pilate to break the legs of the crucified ones (v. 31b), the soldiers came to break the legs of them all, they broke the legs of the ones on either side of Jesus (v. 32), and because Jesus was already dead, they did not break his legs (v. 33; see Swartley 2013:443); and secondly, they did not pierce the sides of those on either side (vv. 31-34), but one of the soldiers pieced the side of Jesus with a spear, and at once blood and water came out (v. 34; see Morris 1995:723). Talbert ([1992]2005) suggests that the soldier 'doubtless aimed at the heart to be sure of his death' (see Talbert [1992]2005:245; cf. Swartley 2013:443). John connects these two incidents with Old Testament prophesies (cf. Ex 12:46; Nm 9:12; Ps 34:20; Zch 12:10; cf. Köstenberger 2004:553-554). From the scriptural and the situational evidence, a reader can infer that Jesus indeed died in a unique manner (cf. Mopsuestia 2010:157). Thomas' demand in John 20:25 is purely Johannine as the

8.Moloney (1998:539) comments, "The use of the verb ballein ("place") is much stronger than a simple "placing" of the finger or the hand. It conveys the idea of an energetic thrust'.

9.As Bruner (2012:1185) comments: 'Thomas is every generation's "modern man", sincere inquirer, and honest seeker. The Gospel is giving all such people, in Thomas' person and through his present insistence, some space, time, and respect'. 
narrator records the event of piercing the side of Jesus (see Swartley 2013:463). The Johannine Jesus accepts the demand of Thomas by stating 'reach out your hand and put it in my side' (see Bruner 2012:1190-1191).

Thomas demands three things for his belief in Jesus' resurrection: firstly, seeing the mark of the nails in Jesus' hands; secondly, putting the finger in the mark of the nails; and thirdly, putting the hand in his side (see Bernard 1929:682). Jesus' response to it cannot be taken as an unpleasant answer of a teacher but as an acceptance of the demand of Thomas before others (v. 27; see Köstenberger 2004:578). A reader cannot demarcate between Thomas and the rest of the interlocutors in their faith responses. All of them believed either after seeing or after seeing and touching the evidence (cf. Thompson 2015:425). At the same time, there is a distinction between Thomas and the rest of the characters as he puts forward detailed evidence as a strong cause for his faith. ${ }^{10}$ Thomas demands to see and touch the body of Jesus, especially two marks that are specified only in the Fourth Gospel. While recording the event of piercing the side in the passion narrative, the narrator would have foreseen Thomas at the climax of his story (see Skinner 2009:76).

\section{'My Lord and my God!'}

Thomas' utterance in John 20:28 brings a clear dénouement to the story. The U-shaped plot structure of the story develops in the following fashion based on the utterance of Thomas: firstly, at the beginning, the story as a whole begins with a reference that the Word was God (Jn 1:1); secondly, at the middle, the Word becomes flesh and dwelt among us, that is, Jesus' mission and ministry in the world; and thirdly, at the closing, the resurrected Jesus reveals that he is Lord and God through the utterance of Thomas (Jn 20:28; see Witherington 1995:344).

\section{Larsson (2001) comments:}

Thomas, by his confession in [John] 20:28, shows that the faith expressed by the Evangelist in [John] 1:1 was in the end 'gained in the actual intercourse of the disciple with Christ'. The incarnate Son is on the same level as the Father in his deeds. ${ }^{11}$ (p. 120)

Thomas' utterance in the Gospel is the strongest and profoundest of all the utterances (see Thompson 2015:423). It brings to the fore the Christological apex of the entire Gospel narrative (see Carson 1991:659).

The above discussion helps us to gain a comprehensive view of the role and character of Thomas within the narrative framework of John 20:1-31. In John 20:1-31, there is a steady progression of his character from the earlier appearances (Jn 11:16 and Jn 14:5). A comparison between the utterances of Thomas and the rest of the disciples (and Mary Magdalene)

10.The narratorial comment in John 19:35 states: "He who saw this has testified so that you also may believe'.

11.Also see Mlakuzhyil (1987:336-337). Keener (2003:1211) further states, 'Thomas' very skepticism makes him the ideal proponent of a high Christology by indicating the greatness of the revelation by which he was convinced'. reveals that he moved away from one extreme understanding (v. 25b) to the other extreme (v. 28). His earlier conviction was to believe in Jesus' resurrection and glorification only on the basis of seeing him and putting his finger in the mark of the nails. By bringing Thomas towards the climax of the story with his revelatory utterance ('My Lord and my God'), the narrator places him in a distinct manner in relation to other characters. Thomas' demand to see the mark of the nails, putting his hands into the mark of the nails and putting his hands into the side (v. 25b) attune the attention of the reader towards his Christological utterance (v. 28). The reader of the story cannot demarcate Thomas on the basis of his demand because all other characters along with him saw, touched and believed. His determination that I will not believe (v. 25b) has to be placed over against his phenomenal proclamation (v. 28). Thomas transforms radically from his earlier conviction that I will not believe to his current belief that Jesus is My Lord and my God. While Jesus' coming a week later with an exclusive focus on Thomas reveals his special love for Thomas, Thomas' confession reveals his love and devotion to Jesus. Thomas saw the glorified Jesus and that persuades him to utter his perception about the divine.

\section{Jesus shows himself (Jn 21:1-25)}

In the epilogue of the Gospel of John (Jn 21:1-25), Thomas' name appears in the fourth context. Although Thomas' role is active in the first three occasions (Jn 11:16; 14:5; 20:24-28), he appears as a passive character in John 21:2. In this case he is counted as one among the seven disciples. At the same time, a reader can understand the characterisation of Chapter 21 as a whole only in relation to Thomas' immediately preceding appearance (Jn 20:24-28). Thomas is the connecting link between the ending of the Book of Glory (Jn 20:24-28) and the beginning of the epilogue (Jn 21:2; see Stibbe 1993:206). The transition and linkage through the appearance of Thomas contribute towards the narrative development of the overall story of John.

\section{Jesus shows himself (Jn 21:1)}

In Chapters 20-21, the narrator reports conversations of the resurrected Jesus with the key figures in the following sequence: Mary Magdalene (Jn 20:1-18); Thomas (Jn 20:24-29); Peter (Jn 21:15-19) and John (Jn 21:20-25; see Schnackenburg 1982:3:352). In Chapter 21, Peter, John, Thomas and Nathanael appear at the outset of the narrative (cf. Sylva 2013:93). After concluding the main body of the Gospel which narrates Thomas' conversation with Jesus (20:24-29), the narrator invites the reader to compare Peter and John with Thomas (see Thompson 2015:436). A symbolical gesture is used as Thomas keeps silence after the pivotal utterance in Chapter 20 and Peter and John continue the discourse (see Blomberg 2001:272).

In John 21:1, the narrator reports that Jesus showed himself again to the disciples by the Sea of Tiberias (see Brant 2011:279). While the disciples already saw (and also touched) and believed in Chapter 20, here it is told that Jesus shows 
himself to the disciples once again (see Witherington 1995:328-351). The repetitive expressions such as 'Jesus showed himself again' and 'and he showed in this way' (v. 1) catch the attention of the reader (cf. Schnackenburg 1982:3:351). Expressions such as 'he said to them' (v. 5), and 'they cast it' and '[they] were not able to haul' (v. 6b), show the collective response of the disciples, of whom Thomas is a key figure (see Sylva 2013:93-99). In verses 7-8, Peter and John are brought to the foreground and the rest of the disciples are backgrounded. The other disciples are dragging in the net full of fish with an implicit understanding that it would have been done under the leadership of Thomas.

\section{Thomas as one among those gathered}

The narrator introduces the disciples with the following formula: 'Gathered there together were' (see Ridderbos 1987:658-659). Then he provides a list of the disciples in the following sequence: Simon Peter, Thomas called the Twin, Nathanael of Cana in Galilee, the sons of Zebedee, and two others of his disciples (see Bonney 2002:172). Schnackenburg (1982) argues that:

[T] he number 7 (the number of fullness in Semitic thought) can have a symbolic value: this group of disciples represents the future community, the Church (cf. also the seven churches in Rv 2-3) (see Schnackenburg 1982:352; cf. Sylva 2013:93-94).

The first and third person plural pronouns in the narrative structure (v. 3) direct the attention of the reader towards the disciples, among whom Thomas is a key figure: Simon Peter said to them, they said to him, we will go with you, they went out and got into the boat, and but that night they caught nothing (see Haenchen 1984:222). It is made clear that Thomas did not detach from the group of disciples even after Jesus' death and resurrection. ${ }^{12}$

On the basis of the above delineation, the presence of Thomas in John 21:2 can be understood as follows: firstly, in the 'gathered there together' group Thomas is counted second only to Peter; secondly, Thomas' connection with Peter and other figures of early Christianity is brought to the fore; thirdly, Thomas is one among the three disciples whose names are specified (i.e. Simon Peter, Thomas called the Twin and Nathanael of Cana in Galilee); fourthly, he was one among those who witnessed the post-resurrection revelation of Jesus in the Galilean context; and lastly, Thomas' silence in the Chapter 21 is meant in the context of his encounter with Jesus in John 20:24-28. While the Gospel as a whole begins with the strongest utterance of Nathanael, it ends with the strongest of all the utterances from Thomas in John 20:28.

Peter appears more often, beginning from John 1:40-42 until Chapter 21. But Peter's character develops through various ups and downs. The unsettled nature of his character is brought to the forefront more convincingly in Chapter 21. While the references to Nathanael create an inclusion with his appearance at the beginning and end of the story, Thomas creates another inclusion by linking the two resurrection stories (i.e. the resurrection of Lazarus with the resurrection of Jesus; Jn 11:16; 20:24-28). The narrator reaches the goal of his thesis statement ('the Word was God', Jn 1:1) through the very utterance of Thomas in John 20:28 ('My Lord and my God', Jn 20:28) (see Bonney 2002:172-173). John 21:1-25 could be considered as a narrative expansion to stabilise the role and function of Thomas even more convincingly through the lagging natures of Peter and John. Thus, we note the grand inclusion that connects Chapter 20 with Chapter 1 (see Thompson 2015:431).

\section{Concluding remarks}

The above analysis of the four passages (Jn 11:1-12:11; 13:1-17:26; 20:1-31; 21:1-25) provides us an extended understanding of the character of Thomas within the framework of John's Gospel. A reader of the Gospel gathers a view concerning Thomas' character with the help of a constellation of phraseologies and expressions embedded within the narrative master plan. While the character of Thomas is backgrounded in the first half of the Gospel, he emerges as a developing character from Chapter 11 onwards. The narrator advances his story to actualise the thesis statement in John 1:1 through persuasive utterances and performative acts of Thomas in the second half. The presentation of Thomas alongside his metaphorical utterances foregrounds his role and status in a unique fashion. Thomas' appearances in the transition episodes make him a figure with symbolical significance. This further helps the reader to view the role and status of Thomas in gnomic and universalistic terms.

The development of Thomas alongside his persuasive speeches unlocks some of the key aspects of the extended story in the following fashion: firstly, Thomas' utterance in John 11:16 directs the attention of the reader from the minor story of Lazarus to the major story of Jesus, that is, a transition of the story from the death of Lazarus to the death of Jesus; secondly, his second utterance in John 14:5 enables the reader to attune herself or himself to the way that connects the world from below with the world from above, that is, with an exclusive claim that Jesus himself is the way to the Father; thirdly, his utterances in John 20:24-28 further directs the reader to understand the identity of Jesus not only as Lord but also as God in a Thomasine idiom; and fourthly, his appearance as one among the seven disciples in John 21:2 and the other disciples' deficient nature make the reader aware of Thomas' unique role within the narrative framework. As the narrator actualised the thesis statement of the Gospel (Jn 1:1) through the character of Thomas in John 20:28, Thomas' placement in the Gospel has to be reckoned with rhetorical significance. As the narrator projects Thomas' character as a loyal, inquisitive and developing model, his character advances towards a new level of faith commitment. The symbolic portrayal of the character of Thomas makes him to appear as gnomic and universalistic in his role and status. 


\section{Acknowledgements}

I acknowledge the mentorship of Prof. Dr James $\mathrm{H}$. Charlesworth during the research.

\section{Competing interests}

The author has declared that no competing interest exists.

\section{Author(s) contributions}

I declare that I am the sole author of this research article.

\section{Ethical consideration}

This article followed all ethical standards for a research without direct contact with human or animal subjects.

\section{Funding information}

This research received no specific grant from any funding agency in the public, commercial or not-for-profit sectors.

\section{Data availability statements}

Data sharing is not applicable to this article as no new data were created or analysed in this study.

\section{Disclaimer}

The views and opinions expressed in this article are those of the author and do not necessarily reflect the official policy or position of any affiliated agency of the author.

\section{References}

Barrett, C.K., 1962, The gospel according to St. John: An introduction with commentary and notes on the Greek text, SPCK, London.

Bennema, C., 2009, Encountering Jesus: Character studies in the gospel of John, 2nd edn., Fortress Press, Minneapolis, MN.

Bernard, J.H., 1929, A critical and exegetical commentary on the gospel according to St. John, ICC, vol. 2, T \& T Clark, Edinburgh.

Blomberg, C.L., 2001, The historical reliability of John's gospel, IVP, Leicester.

Bonney, W., 2002, Caused to believe: The doubting Thomas story at the climax of John's Christological narrative, Brill, Leiden.

Bowman, J., 1975, The Fourth Gospel and the Jews: A study in R. Abika, Esther and the gospel of John, The Pickwick Press, Pittsburgh, PA.

Brant, J.A., 2004, Dialogue and drama: Elements of Greek tragedy in the Fourth Gospel, Hendrickson Publishers, Peabody, MA.

Brant, J.A., 2011, John, PCNT, Baker, Grand Rapids.

Brouwer, W., 2000, The literary development of John 13:17: A chiastic reading, SBLDS 182, SBL, Atlanta, GA.

Bruce, F.F., 1983, The gospel of John: Introduction, exposition and notes, Eerdmans, Grand Rapids, MI.

Bruner, F.D., 2012, The gospel of John: A commentary, Eedrmans, Grand Rapids, MI.

Bultmann, R., 1971, The gospel of John: A commentary, The Westminster Press, Philadelphia, PA.

Byrne, B., 1991, Lazarus: A contemporary reading of John 11:1-46, The Liturgical Press, Collegeville, MI.

Carson, D.A., 1991, The gospel according to John, Eerdmans, IVP, Leicester, Grand Rapids, MI.

Carter, W., 2006, John: Storyteller, interpreter, evangelist, Hendrickson Publishers, Peabody, MA.
Charlesworth, J.H., 1995, The beloved disciple: Whose witness validates the gospel of John, Trinity Press International, Valley Forge, PA.

Collins, R.F., 1990, These things have been written: Studies on the Fourth Gospel, Peeters, Louvain.

DeConick, A.D., 2001, Voices of the mystics: Early Christian discourse in the gospels of John and Thomas and other ancient Christian literature, JSNTSS 157, Sheffield Academic, Sheffield.

Duke, P.D., 1985, Irony in the Fourth Gospel, John Knox Press, Atlanta, GA.

Fitzmyer, J.A., [1981]1991, Kurios, EDNT, vol. 2, Eerdmans, Grand Rapids, MI.

Haenchen, E., 1984, A commentary on the gospel of John chapters 7-21, vol. 2, Fortress Press, Philadelphia, PA.

Hendriksen, W., 1954, Exposition of the gospel according to John, New Testament Commentary, Baker, Grand Rapids, MI.

Howard-Brook, W., 1997, John's gospel and the renewal of the Church, Orbis, New York.

Köstenberger, A.J., 2004, John, ECNT, Baker, Grand Rapids, MI.

Keener, C.S., 2003, The Gospel of John: A Commentary, vol. 2, Hendrickson, Peabody.

Larsson, T., 2001, God in the Fourth Gospel: A hermeneutical study of the history of interpretation, ConiectaneaBiblica: New Testament Series 35, Almqvist and Wiksell International, Stockholm.

Lincoln, A.T., 2005, The gospel according to Saint John, BNTC, Continuum, London.

Mlakuzhyil, G., 1987, The Christocentric literary structure of the Fourth Gospel, Editrice Pontificio Instituto Biblico, Roma.

Moloney, F.J., 1996, Signs and shadows: Reading John 5-12, Fortress Press, Minneapolis, MN.

Moloney, F.J., 1998, The gospel of John, Sacra Pagina 4, The Liturgical Press, Collegeville, MI.

Mopsuestia, T., 2010, Commentary on the gospel of John, ACT, IVP, Downers Grove, IL.

Morris, L., 1995, The gospel according to John, NICNT, revised edn., Eerdmans, Grand Rapids, MI.

Newman, B.M. \& Nida, E.A., 1980, A handbook on the gospel of John, United Bible Societies, New York.

Neyrey, J.H., 2007, The gospel of John, NCBC, University Press, Cambridge.

Petersen, N.R., 1993, The gospel of John and the sociology of light: Language and characterization in the Fourth Gospel, Trinity Press International, Valley Forge, PA.

Popp, T., 2013, 'Thomas: Question marks and exclamation marks', in S.H. Hunt, D.F. Tolmie \& R. Zimmermann (eds.), Character studies in the Fourth Gospel: Narrative approaches to seventy figures in John, pp. 504-529, WUNT, Mohr Siebeck, Tübingen.

Rensberger, D., 1988, Johannine faith and liberating community, Westminster Press, Philadelphia, PA.

Ridderbos, H., 1987, The gospel of John: A theological commentary, Eerdmans, Grand Rapids, MI.

Schnackenburg, R., 1982, The gospel according to St. John, vol. 3, Herder and Herder, New York.

Schnackenburg, R., 1984, The gospel according to St. John, vols. 1-3, Herder and Herder, New York.

Skinner, C.W., 2009, John and Thomas: Gospels in conflict? Johannine characterization and the Thomas question, PTMS, Pickwick Publications, Eugene, OR.

Stibbe, M.W.G., 1993, John. Readings: A new Biblical commentary, Sheffield Academic, Sheffield.

Stibbe, M.W.G., 1994, John's gospel, Routledge, London.

Story, C.I.K., 1997, The Fourth Gospel: Its purpose, pattern, and power, Ragged Edge Publication, Shippensburg, PA.

Swartley, W.M., 2013, John, BCBC, Herald Press, Harrisonburg, VA.

Sylva, D., 2013, Thomas: Love as strong as death: Faith and commitment in the Fourth Gospel, LNTS 434, Bloomsbury, London.

Talbert, C.H., [1992]2005, Reading John: A literary and theological commentary on the Fourth Gospel and the Johannine Epistles, revised edn., Smyth and Helwys, Macon, GA.

Thomaskutty, J., 2018, Saint Thomas the apostle: New Testament, apocrypha, and historical traditions, Jewish and Christian Texts Series 25, Bloomsbury T \& T Clark, London.

Thompson, M.M., 2015, John: A commentary, NTL, Westminster John Knox, Louisville, KY.

Von Wahlde, U.C., 2010, The gospel and letters of John, vol. 2, Eerdmans, Grand Rapids, MI.

Waetjen, H.C., 2005, The gospel of the beloved disciple: A work in two editions, T \& T Clark, London.

Witherington, B., 1995, John's wisdom: A commentary on the Fourth Gospel, Westminster John Knox Press, Louisville, KY. 